\title{
Leaf protein production from energy willow leaves
}

\author{
MATTI NÄSI \\ Department of Animal Husbandry, University of Helsinki, 00710 Helsinki 71
}

\begin{abstract}
The extraction of protein from leaves of two energy willow clones (Salic cv. Aquatica and S. viminalis) and the chemical composition and nutritive value of the leaf fractions were investigated in six experiments. The preservation of leaf juice and wet leaf protein concentrate (LPC) was also studied. The extraction of juice averaged $33 \%$ of the fresh weight, and the extraction ratios of dry matter (DM) and crude protein $(\mathrm{CP})$ were $10.5 \%$ and $2.9 \%$. The percentages of juice DM, CP and TP (true protein) separated in LPC were $6 \%, 21 \%$ and $48 \%$, respectively. The separation values were higher when LPC was precipitated by heating than by acidification. Removal of nutrients from the leaves was low and there were only minor differences in composition between the pressed pulp and the leaves. The leaf juice contained $8.3 \%$ DM, of which $20.9 \%$ was ash, $4.9 \%$ CP, $1.9 \%$ TP and $43.2 \%$ sugars. The LPC had an average DM content of $19.6 \%$, CP being $21.4 \%$ and TP $19.5 \%$ of DM. The in vitro digestibility and pepsin- $\mathrm{HCl}$-solubility of the protein were low. The mean tannin content of the LPC averaged $3.6 \%$ of DM. The mean lysine and methionine contents of the LPC were low, 3.3 and $1.5 \mathrm{~g} / 16 \mathrm{~g} \mathrm{~N}$, respectively. The preservation of the leaf juice was satisfactory even without addition of preservative. Preservation of wet LPC was good with additives used at the $1.0 \% \mathrm{v} / \mathrm{w}$ level. Leaf protein extraction was low and the nutritive value of LPC was not particularly high. This may have been partly due to the late date of harvesting and to the fact that the leaves were frozen for storage.
\end{abstract}

\section{Introduction}

Tree leaves contain considerable amounts of protein and it has been suggested that they may be suitable for leaf protein extraction (NEHRING 1965, SIREN et al. 1970, NÄSI and POHJONEN 1981, CISZUK and MURPHY 1982). However, harvesting the leaves in natural stands is difficult to mechanise and practical difficulties have been encountered in extracting protein from foliage (PIRIE 1978). CHEN et al. (1979) reported quite satisfactory recoveries of leaf protein from hybrid poplar leaves. As a by-product of biotic energy production, fastgrowing energy woods have had an annual foliage yield of 5-10 tn/hectare/year. Leaves of energy willow have a high content of protein and the ratio of protein to fibre remains fairly constant throughout the season (NÄSI and POHJONEN 1981, 1983). Methods could be developed for the separating leaves from the stem yield or the willows at the autumn harvest, when the biomass yield is highest, and the leaf crop could then be fractionated into leaf juice and pressed leaf pulp. The short-rotation forest planta- 
tions can supply sufficient amounts of foliage for fractionation. Integrated forest production of green biomass for forage and wood for fuel and energy would improve land utilization (PLASKETT 1980, NÄSI and POHJONEN 1981, 1983). Finland has abundant marginal areas, such as peatlands, that are suitable for energy-wood production, and great importance is attached to increasing the country's domestic energy supply.

The purpose of this study was to fractionate energy willow leaves, in order to obtain leaf protein, and to investigate the chemical composition and nutritive value of the leaf fractions. The preservation of the leaf juice and wet leaf protein concentrate was also examined.

\section{Material and methods}

The experiment consisted of six willow leaf fractionation tests, three preservation tests with leaf juice and one with wet leaf protein concentrate. The willow leaves were from 3-4-year-old energy stands planted by the Forest Research Institute in Kannus. The fertilizers applied to the willow stands were N $150 \mathrm{~kg}, \mathrm{P} 60 \mathrm{~kg}$ and K $255 \mathrm{~kg}$ per ha. In 1980, $1066 \mathrm{~kg}$ leaves were collected from a clone of Salix cv. Aquatica and $39 \mathrm{~kg}$ leaves from a clone of $S$. viminalis between 25 September and 5 October and in the following year $284 \mathrm{~kg}$ from S. Aquatica and $80 \mathrm{~kg}$ from S. viminalis between 7 and 17 September.

The leaves were stripped by hand from the stems, packed in plastic sacks and kept deep frozen until processed. After thawing overnight, the leaves were pulped with a laboratory cutter and juice was expressed hydraulically from the pulp as described by NÄSI $(1983 \mathrm{a})$. The leaf protein was precipitated by heating the juice with steam to $85^{\circ} \mathrm{C}$ or by adding $0.5 \%$ w $/ \mathrm{v} \mathrm{HCl}$, or by combined heating and acid treatment. The precipitated leaf protein was separated from the juice by cloth filtration.

Leaf juice was preserved using three different additives, AIV I containing $27 \%$ formic acid and $22 \%$ hydrochloric acid, formic acid or Viher solution (20\% formaldehyde and $24 \%$ acetic acid), applied at concentrations of 0.25 $\%$ or $0.5 \% \mathrm{w} / \mathrm{v}$ to $1000 \mathrm{~g}$ of leaf juice. Bottles of juice covered with parafilm were stored for 120 days at $+6-8^{\circ} \mathrm{C}$. Wet leaf protein concentrate was preserved with $1 \% \mathrm{w} / \mathrm{v}$ formic acid or $0.2,0.4$ or $0.6 \%$ Viher solution and stored in $500 \mathrm{~g}$ plastic boxes.

The chemical composition and nutritive value or the leaf fractions were analysed as presented by NÄSI (1983 a) and the success of ensilage was evaluated as described in detail by NÄSI (1983 b).

\section{Results and discussion}

The juice expressed from S. cv. Aquatica in 1980 and 1981 represented 28.6 and $35.5 \%$, respectively, of the fresh weight of the leaves. The corresponding values for $S$. viminalis were $39.2 \%$ and $40.6 \%$. The dry 
matter (DM) of the leaves was fairly high, $26.4 \%$, compared with that of some crops used by NÄSI (1983 a ), e.g. and so the extraction values were low. In 1981 the leaves of S. cv. Aquatica were very dry, 35,3\% DM, and water corresponding to $10 \%$ of the fresh weight was added in pulping. PIRIE (1978) reported that the extraction values for juice are rather low in most of the studies where tree leaves have been used in protein production.

The extraction ratios of the components of the juice from leaves of $S . c v$. Aquatica were as follows: DM $9.8 \%$, ash $24.1 \%$, crude protein (CP) $3.3 \%$ and true protein (TP) $1.8 \%$. The corresponding percentages for $S$. viminalis were $11.3,34,6,2.5$ and $0.8 \%$. These values were considerably lower than those for juice extracted from various crops by the same methods (NÄSI 1983 a). The DM and CP extraction values for grass and clover averaged 22.6 and $24.1 \%$. With hybrid poplar leaves, alkaline treatment and acid precipitation gave CP extraction of 55-70\% (CHEN et al. 1979). In the present study the leaves were deep frozen after harvesting and thawed before processing. This treatment may have caused changes in the plant cells which decreased extraction of protein. The leaves also had rather low $\mathrm{pH}$ values, $\mathrm{pH}$ 5.3-5.6. The structure of tree leaves may make the cells less easily ruptured during pulping and the harvesting time, September-October, which is rather late for Finland, may also have decreased protein extractability, though no marked changes in chemical composition were observed during autumn in the clones used here (NÄSI and POHJONEN 1983).

The percentages of the juice components in the leaf protein concentrate (LPC) are presented in table 1. The values are rather low. The protein separated from $S$. cv. Aquatica in 1981 was less than half that obtained in 1980 and the recoveries from $S$. viminalis were also lower than from $S . c v$. Aquatica in 1980. The precipitation by heating was almost twice as high as when acidification was used. CHEN et al. (1979), however, found acid precipitation more efficient than other methods with poplar leaves.

Table 2 shows the chemical composition and in vitro digestibilities of foliage and pressed residues. On average the DM content of the leaves increased by $9.3 \%$ units in pressing. Juice extraction was rather small and nutrient removal was poor, so that the differences in chemical composition between the leaves and pulp were fairly small. Measured on a DM basis, the crude fibre content was $2 \%$ units higher. In vitro organic matter digestibility was $7.0 \%$ units lower on average in pulp and pepsin- $\mathrm{HCl}$-soluble protein was $1.6 \%$ units lower than in the original material. The composition and digestibility of the pressed leaves were reasonably satisfactory for the purpose of ruminant feeding.

The DM content of the leaf juice averaged $8.3 \%$ and contained $20.9 \%$ ash, $4.9 \% \mathrm{CP}, 1.9 \% \mathrm{TP}$ and $43.2 \%$ sugars. S. viminalis juice had slightly lower values for CP and TP (Table 3 ). Willow leaf juice had a low protein content compared with grass and clover juice, in which $\mathrm{CP}$ and TP averaged $21.5 \%$ and $10.7 \%$ of DM (NÄSI $1982 \mathrm{a}$ ).

The leaf protein concentrate obtained from willow juice had rather a low protein percentage compared with LPCs from other crops (Table 4). Grass and clover LPC had twice as high a protein content (NÄSI 1983 a). The crude 
Table 1. Percentages of juice components in leaf protein concentrate obtained by different methods.

\begin{tabular}{lcccc}
\hline \multirow{2}{*}{$\begin{array}{l}\text { Precipitation } \\
\text { method }\end{array}$} & \multicolumn{3}{c}{ Percentage of juice component in LPC } \\
\cline { 2 - 5 } & $\begin{array}{c}\text { Fresh } \\
\text { weight }\end{array}$ & $\begin{array}{c}\text { Dry } \\
\text { matter }\end{array}$ & $\begin{array}{c}\text { Crude } \\
\text { protein }\end{array}$ & $\begin{array}{c}\text { True } \\
\text { protein }\end{array}$ \\
\hline $\begin{array}{l}\text { Salix cv. Aquatica }(1980) \\
\text { heating }\left(85^{\circ} \mathrm{C}\right)\end{array}$ & 5.3 & 11.5 & 38.3 & 66.8 \\
$\quad \begin{array}{l}\text { heating +acidification } \\
\text { acidification }(\mathrm{HCl} 0.5 \% \mathrm{v} / \mathrm{w})\end{array}$ & 5.6 & 11.3 & 35.9 & 60.1 \\
$\begin{array}{l}\text { S. Aquatica }(1981) \\
\text { heating }\left(85^{\circ} \mathrm{C}\right)\end{array}$ & 2.2 & 4.8 & 16.4 & 27.9 \\
$\begin{array}{l}\text { S. viminalis }(1981) \\
\text { heating }\end{array}$ & 0.8 & 1.6 & 5.8 & 17.0 \\
\hline
\end{tabular}

Table 2. Composition and in vitro digestibility of willow leaves and pressed leaves (\% DM).

\begin{tabular}{|c|c|c|c|c|c|c|c|c|c|c|c|}
\hline & $\begin{array}{c}\text { Dry } \\
\text { matter }\end{array}$ & Ash & $\begin{array}{l}\text { Crude } \\
\text { protein }\end{array}$ & $\begin{array}{c}\text { True } \\
\text { protein }\end{array}$ & $\begin{array}{l}\text { Ether } \\
\text { extract }\end{array}$ & $\begin{array}{l}\text { Crude } \\
\text { fibre }\end{array}$ & N.F.E. & Sugars & Tannins & $\begin{array}{c}\text { Pepsin- } \\
\mathrm{HCl} \\
\text { solube } \\
\text { protein }\end{array}$ & $\begin{array}{c}\text { In vitro } \\
\text { Organic } \\
\text { matter } \\
\text { digestibility }\end{array}$ \\
\hline \multicolumn{12}{|l|}{ Salix cv. Aquatica } \\
\hline leaves (1980) & 25.4 & 7.5 & 19.9 & 18.3 & 5.2 & 13.5 & 53.8 & 16.1 & 3.2 & 70.2 & 69.0 \\
\hline pulp & 31.2 & 6.6 & 21.6 & 20.1 & 5.2 & 15.1 & 51.5 & 11.2 & 3.2 & 66.0 & 57.3 \\
\hline leaves (1981) & 25.5 & 7.2 & 15.4 & 14.0 & 5.2 & 17.2 & 55.1 & 11.5 & 3.0 & 33.1 & 46.4 \\
\hline pulp & 35.1 & 5.5 & 17.1 & 16.1 & 5.6 & 19.0 & 52.9 & 6.8 & 3.5 & 32.7 & 41.4 \\
\hline \multicolumn{12}{|l|}{ S. viminalis } \\
\hline leaves (1980) & 27.8 & 8.0 & 18.0 & 16.4 & 5.3 & 15.0 & 53.6 & 9.9 & 5.4 & 64.9 & 61.3 \\
\hline pulp & 41.3 & 6.0 & 19.7 & 17.3 & 5.5 & 17.7 & 51.1 & 4.9 & 5.3 & 62.5 & 55.8 \\
\hline leaves (1981) & 27.1 & 7.5 & 18.1 & 16.6 & 4.4 & 15.6 & 54.4 & 16.3 & 6.0 & 52.6 & 53.2 \\
\hline pulp & 35.2 & 5.2 & 22.7 & 21.4 & 5.3 & 16.9 & 50.0 & 10.3 & 5.4 & 53.3 & 47.3 \\
\hline \multicolumn{12}{|l|}{ Mean values } \\
\hline leaves & 26.4 & 7.6 & 17.9 & 16.3 & 5.0 & 15.3 & 54.2 & 13.5 & 4.4 & 55.2 & 57.5 \\
\hline pulp & 35.7 & 5.8 & 20.3 & 18.7 & 5.4 & 17.2 & 51.4 & 8.3 & 4.4 & 53.6 & 50.5 \\
\hline
\end{tabular}

Table 3. Chemical composition of leaf juice extracted clones of Salix cv. Aquatica and S. viminalis.

\begin{tabular}{|c|c|c|c|c|c|c|c|c|c|}
\hline & \multirow{2}{*}{$\begin{array}{c}\text { Dry } \\
\text { matter } \\
\%\end{array}$} & \multicolumn{2}{|c|}{ Ash } & \multicolumn{2}{|c|}{ Crude protein } & \multicolumn{2}{|c|}{ True protein } & \multicolumn{2}{|c|}{$\begin{array}{l}\text { Water soluble } \\
\text { carbohydrates }\end{array}$} \\
\hline & & $\%$ & $\%$ in DM & $\%$ & $\%$ in DM & $\%$ & $\%$ in DM & $\%$ & $\%$ in DM \\
\hline \multicolumn{10}{|c|}{ S. cv. Aquatica } \\
\hline 1980 & 8.8 & 1.5 & 18.4 & 0.6 & 7.3 & 0.4 & 3.9 & 4.2 & 47.6 \\
\hline 1981 & 8.7 & 1.5 & 17.8 & 0.4 & 4.1 & 0.1 & 1.3 & 3.9 & 44.6 \\
\hline \multicolumn{10}{|l|}{ S. viminalis } \\
\hline 1980 & 7.8 & 2.0 & 25.6 & 0.4 & 4.5 & 0.1 & 1.5 & 3.0 & 39.0 \\
\hline 1981 & 8.0 & 1.8 & 22.0 & 0.3 & 3.6 & 0.1 & 1.0 & 3.3 & 41.7 \\
\hline Mean values & 8.3 & 1.7 & 20.9 & 0.4 & 4.9 & 0.2 & 1.9 & 3.6 & 43.2 \\
\hline
\end{tabular}


Table 4. Composition and in vitro digestibility of leaf protein concentrates obtained from willow leaf juice by different methods (\% DM).

\begin{tabular}{|c|c|c|c|c|c|c|c|c|c|c|c|}
\hline & $\begin{array}{c}\text { Dry } \\
\text { matter }\end{array}$ & Ash & $\begin{array}{l}\text { Crude } \\
\text { protein }\end{array}$ & $\begin{array}{c}\text { True } \\
\text { protein }\end{array}$ & $\begin{array}{l}\text { Ether } \\
\text { extracts }\end{array}$ & $\begin{array}{l}\text { Crude } \\
\text { fibre }\end{array}$ & NFE & Sugars & Tannins & $\begin{array}{c}\text { Pepsin- } \\
\text { HCl } \\
\text { soluble } \\
\text { protein }\end{array}$ & $\begin{array}{c}\text { In vitro } \\
\text { organic } \\
\text { matter } \\
\text { digestibility }\end{array}$ \\
\hline \multicolumn{12}{|c|}{ S. cv. Aquatica (1980) } \\
\hline heating & 19.0 & 9.4 & 24.3 & 22.6 & 6.7 & 5.3 & 54.3 & 18.8 & 3.4 & 58.9 & 66.4 \\
\hline $\begin{array}{l}\text { heating + } \\
\text { acidification }\end{array}$ & 17.8 & 9.3 & 23.1 & 20.7 & 6.0 & 3.3 & 58.4 & 17.7 & 3.9 & 59.2 & 71.9 \\
\hline acidification & 19.3 & 9.0 & 25.1 & 22.7 & 7.0 & 3.9 & 55.0 & 16.7 & 3.3 & 68.9 & 57.8 \\
\hline \multicolumn{12}{|c|}{ S. cv. Aquatica (1981) } \\
\hline heating & 17.9 & 10.7 & 15.3 & 13.6 & 4.8 & 11.5 & 57.8 & 16.3 & 2.8 & 4.8 & 51.8 \\
\hline \multicolumn{12}{|c|}{ S. viminalis (1981) } \\
\hline heating & 23.9 & 19.0 & 19.0 & 17.9 & 3.6 & 8.7 & 49.7 & 5.3 & 4.8 & 4.5 & 42.1 \\
\hline Mean values & 19.6 & 11.5 & 21.4 & 19.5 & 5.6 & 6.5 & 55.0 & 15.0 & 3.6 & 41.3 & 58.0 \\
\hline
\end{tabular}

Table 5. Amino acid composition of leaf protein concentrates obtained from willow leaves by heating.

\begin{tabular}{lcc}
\hline $\begin{array}{l}\text { Amino acid } \\
\text { g/16 g N }\end{array}$ & $\begin{array}{c}\text { Salix co. Aquatica } \\
1980\end{array}$ & $\begin{array}{c}\text { S. viminalis } \\
1981\end{array}$ \\
\hline Alanine & 6.6 & 5.9 \\
Arginine & 3.3 & 4.9 \\
Aspartic acid & 8.7 & 9.4 \\
Glutamic acid & 10.2 & 11.0 \\
Glycine & 4.3 & 5.2 \\
Isoleucine & 7.3 & 4.2 \\
Leucine & 9.0 & 8.4 \\
Lysine & 2.7 & 3.9 \\
Methionine & 1.7 & 1.3 \\
Phenylalanine & 5.4 & 5.4 \\
Proline & 3.3 & 4.8 \\
Serine & 4.7 & 4.5 \\
Threonine & 6.2 & 4.4 \\
Tyrosine & 4.8 & 2.7 \\
Valine & 8.6 & 5.2 \\
\hline
\end{tabular}

fat content of willow LPC was 5-7 \% of DM, which exceeded the values of other LPC's. Pepsin-HCl-soluble protein and in vitro organic matter digestibility were rather low. The pepsin- $\mathrm{HCl}$ solubility of the crude protein in LPC was only $4.5-4.8 \%$ in 1981 , when the willow leaves were infected by a rust fungus. In 1980 the values were over ten times as high. The tannin content of the LPC was 2.8-4.8\% of DM and that substance reduces digestibility.

The amino acid composition of the leaf protein in presented in Table 5. The amounts of essential amino acids were not sufficient for feeding to monogastric animals. The lysine content was only $2.7-3.9 \mathrm{~g} / 16 \mathrm{~g} \mathrm{~N}$ and that 
Table 6. Changes during storage of willow juice (Salix cv. Aquatica) preserved with different additives.

\begin{tabular}{|c|c|c|c|c|c|c|c|c|c|}
\hline \multirow[t]{2}{*}{ Preservation } & \multicolumn{3}{|c|}{$\mathrm{pH}$} & \multirow[t]{2}{*}{ DM } & \multicolumn{3}{|c|}{ Dry matter \% } & \multirow{2}{*}{$\begin{array}{c}\text { Lactic } \\
\text { acid. \% }\end{array}$} & \multirow{2}{*}{$\begin{array}{c}\mathrm{NH}_{3}-\mathrm{N} \\
\mathrm{mg} / \mathrm{l}\end{array}$} \\
\hline & & day 1 & day 120 & & $\begin{array}{c}\text { Crude } \\
\text { protein }\end{array}$ & $\begin{array}{c}\text { True } \\
\text { protein }\end{array}$ & $\begin{array}{c}\text { Water- } \\
\text { soluble } \\
\text { carbohydr. }\end{array}$ & & \\
\hline Fresh & & 5.3 & - & 8.8 & 7.3 & 3.9 & 47.6 & 0.02 & 13 \\
\hline No preservative & * & 5.6 & 5.2 & 9.1 & 6.7 & 3.5 & 40.0 & 0.02 & 21 \\
\hline $0.25 \%$ v/w AIV I & * & 4.4 & 4.6 & 9.2 & 6.6 & 3.4 & 40.5 & 0.02 & 18 \\
\hline $0.25 \% \mathrm{v} / \mathrm{w}$ formic acid & & 4.3 & 4.4 & 9.4 & 6.6 & 3.4 & 42.9 & 0.01 & 22 \\
\hline $0.25 \% \mathrm{v} / \mathrm{w}$ Viher Solution & $*$ & 5.0 & 4.9 & 9.3 & 7.1 & 3.6 & 40.9 & 0.02 & 20 \\
\hline $0.5 \%$ v/w AIV I & * & 4.0 & 4.1 & 9.3 & 6.4 & 3.5 & 41.3 & 0.01 & 18 \\
\hline $0.5 \% \mathrm{v} / \mathrm{w}$ formic acid & & 3.8 & 4.0 & 9.4 & 6.8 & 3.4 & 42.1 & 0.01 & 19 \\
\hline $0.5 \% \mathrm{v} / \mathrm{w}$ Viher solution & * & 4.7 & 4.8 & 9.5 & 7.2 & 3.9 & 42.3 & 0.01 & 19 \\
\hline
\end{tabular}

* Surface moulding

Table 7. Changes during storage of leaf protein concentrate from willow leaves (Salix cv. Aquatica).

\begin{tabular}{|c|c|c|c|c|c|c|c|}
\hline \multirow[t]{2}{*}{ Preservation } & \multicolumn{2}{|r|}{$\mathrm{pH}$} & \multirow{2}{*}{$\frac{\mathrm{DM}}{\%}$} & \multicolumn{3}{|c|}{ In dry matter, $\%$} & \multirow{2}{*}{$\begin{array}{c}\text { DM loss, } \\
\%\end{array}$} \\
\hline & 1 day & day 120 & & $\begin{array}{l}\text { Crude } \\
\text { protein }\end{array}$ & $\begin{array}{c}\text { True } \\
\text { protein }\end{array}$ & $\begin{array}{l}\text { Water- } \\
\text { soluble } \\
\text { carbo- } \\
\text { hydrates }\end{array}$ & \\
\hline Fresh & 5.3 & - & 18.7 & 24.2 & 22.0 & 17.7 & - \\
\hline No preservative & 5.3 & 4.6 & 17.8 & 29.3 & 27.1 & 3.9 & 12.7 \\
\hline Formic acid $1.0 \mathrm{v} / \mathrm{w} \%$ & 3.5 & 3.5 & 18.9 & 24.8 & 22.7 & 19.3 & 1.1 \\
\hline $\mathrm{HCl} 0.5 \%$ v/w & 3.9 & 3.9 & 16.0 & 29.2 & 25.2 & 2.3 & 14.3 \\
\hline $\begin{array}{r}\mathrm{HCl} 0.5 \% \mathrm{v} / \mathrm{w}+\mathrm{Viher} \\
\text { solution } 0.2 \% \mathrm{v} / \mathrm{w}\end{array}$ & 3.9 & 3.9 & 15.8 & 29.2 & 25.2 & 2.3 & 15.1 \\
\hline solution $0.4 \%$ v/w & 3.8 & 3.9 & 16.0 & 28.8 & 26.1 & 3.1 & 15.0 \\
\hline solution $0.6 \% \mathrm{v} / \mathrm{w}$ & 3.8 & 3.9 & 17.9 & 24.9 & 21.9 & 17.4 & 1.9 \\
\hline
\end{tabular}

of methionine 1.3-1.7 g, corresponding to the values for grain. The isoleucine, threonine, tyrosine and valine contents of LPC were considerably higher in S. cv. Aquatica than in S. viminalis. The LPC of grass and clover had a slightly better composition of essential amino acids than willow LPC. CHEN et al. (1979) report higher amounts of essential amino acids in LPC made from hybrid poplar leaves, but the leaves were collected earlier than here and the stage of maturation of the leaves was found to have a strong effect on the amino acid contents. SIREN et al. (1970) reported a favourable amino acid composition in the leaves of cultivated plantations.

There were only small changes in the composition of the juice during storage when it was preserved with the different additives. Even in the juice without additive fermentation was very slight (Table 6). The lactic acid content did not increase and there was only a minor increase in ammonia. Mould formed on the juice surface with all the additives except formic acid. Growth of microorganisms in juice usually causes very rapid deterioration, with loss of soluble sugars and protein (NÄSI $1983 \mathrm{~b}$ ). 
In preservation experiments with grass and clover juice (NÄSI $1983 \mathrm{~b}$ ) preservation was successfull when the $\mathrm{pH}$ was reduced to 3.5-4.0. Willow juice contains some substances, e.g. tannins, which prevent microbial growth.

Wet leaf protein concentrate was preserved well with $1.0 \%$ formic acid or with $0.6 \%$ Viher solution. Fermentation occurred with $0.2-0.4 \%$ levels of Viher solution. Leaf protein was precipitated by acidification with $0.5 \%$ $\mathrm{v} / \mathrm{w} \mathrm{HCl}$ when Viher solution was used. In the samples without preservative DM losses were $13-14 \%$ and in those with Viher solution at the $0.2-0.4 \%$ level they were $15 \%$.

Leaf protein extraction from willow leaves was low in these experiments, probably because the foliage was harvested late in the season. Storage by freezing may also have affected extractability of protein from the cells. Extraction of leaf protein from foliage harvested at an earlier growth stage should be examined in future experiments. The nutritive value of the LPC was not high, since the protein content was rather low and in vitro digestibility was poor. The amino acid composition was also insufficient for monogastric animals. Tree leaves contain considerable amounts of essential amino acids, however, and with suitable techniques it should be possible to extract protein from willow leaves.

Acknowledgements. The author wishes to thank Mr. Kari Saloheimo, M.Sc.Agr, and Mr. Timo Laitinen for technical assistance.

\section{References}

CHEN, C. P., ROY, D. N. \& ANDERSON, H. W. 1979. Hybrid poplar leaves as a source of protein and other useful products. In Poplar research, management and utilization in Canada. Ontario Min. Nat. Res. For. Res. Infor. Paper No 102 Rap. 28, 12 p.

CISZUK, P. \& MURPHY, M. 1982. Digestion of crude protein and organic matter of leaves by rumen microbes in vitro. Swedish J. agric. Res. 12: 35-40.

NEHRING, K. 1965. Laub- und Reisigfutterstoffe. In Handbuch der Futtermittel 2: 10-27. Paul Parey Hamburg.

NÄSI, M. 1983 a. Extraction of leaf protein from green crops. Chemical composition and nutritive value of products of fractionation J. Scient. Agric. Soc. Finl. 54: 000-000.

-1983 b. Preservation of grass juice and wet leaf protein concentrate J. Scient. Agric. Soc. Finl. 55: 000-000.

— \& POHJONEN, V. 1981. Green fodder from energy forest farming. J. Scient. Agric. Soc. Finl. 53: 161-167.

- \& POHJONEN, V. 1983. Seasonal changes of biomass accumulation, chemical composition and nutritive value of energy willow foliage. J. Scient. Agric. Soc. Finl. 55: 000-000.

PIRIE, N.W. 1978. Leaf protein and other aspects of fodder fractionation. 169 p. Cambridge Univ. Press London.

PLASKETT, L. G. 1980. The potential role of crop fractionation in the production of energy from biomass. First E.C. Conf. pp 110-117. Appl. Sci. Publ. London.

SIRÉN, G., BLOMBÄCK, B. \& ALDEN, T. 1970. Proteins in forest tree leaves. Inst. for skogsförungring. Rapp och uppsatser No 28,22 p.

Ms received February 23, 1983 


\section{Lehtiproteiinin tuottaminen energiapajun lehdistä}

\section{Matti Näsi}

Helsingin yliopisto, kotieläintieteen laitos, 00710 Helsinki 71

Tutkimuksessa selvitettiin lehtivalkuaisen erottamista kahden energiapajukloonin lehdistä (Salix cv. Aquatica ja S. viminalis) ja tutkittiin fraktioitujen tuotteiden koostumusta ja rehuarvoa. Lehtimehun ja lehtivalkuaistiivisteen säilöntää myös selvitettiin. Lehtimehusaanto oli $33 \%$ tuoreiden lehtien painosta. Lehtimehussa erottui $10.5 \%$ kuiva-aineesta ja $2.9 \%$ raakavalkuaista. Mehun sisältämästä raaka- ja puhdasvalkuaisesta saatiin saostettua $21 \%$ ja 48 \% lehtivalkuaistiivisteeseen. Lehtimehun kuiva-ainepitoisuus oli $8.3 \%$, josta oli tuhkaa 20.9 $\%$, raakavalkuaista $4.9 \%$ ja sokereita $43.2 \%$. Lehtivalkuaistiivisteessä oli raakavalkuaista 21.4 $\%$ ja puhdasvalkuaista $19.5 \%$ kuiva-aineesta. Lehtivalkuaistiivisteen in vitro sulavuudet olivat suhteellisen alhaisia. Lehtimehun ja lehtivalkuaistiivisteen säilyvyys oli hyvä.

Lehtivalkuaisen erottuminen suoritetussa kokeessa jäi suhteellisen alhaiseksi ilmeisesti johtuen pajunlehtien myöhäisestä korjuuajankohdasta sekä lehtien pakkasvarastoinnista. Lehtivalkuaistiivisteen valkuaispitoisuus ja aminohappokoostumus ovat puutteellisia yksimahaisten ruokintaa ajatellen. 